\title{
Nauplius
}

The Journal of The

Brazilian Crustacean Society

This article is part of the tribute offered

by the Brazilian Crustacean Society

in memoriam of Michael Türkay

outstanding contribution to Carcinology

e-ISSN 2358-2936

www.scielo.br/nau www.crustacea.org.br

Original Article

\section{Length/weight relationship and condition factor of Macrobrachium jelskii (Miers, 1877) and M. brasiliense (Heller, 1862) (Decapoda, Palaemonidae) in two locations in the state of São Paulo}

Fabiano Gazzi Taddei ${ }^{1,3}$, Daphine Ramiro Herrera², Thiago Maia Davanso ${ }^{2}$, Thiago Elias da Silva ${ }^{3}$, Rogério Caetano da Costa $^{2}$ and Adilson Fransozo ${ }^{3}$

1 Laboratório de Estudos de Crustáceos da Amazônia (LECAM), Universidade do Estado do Amazonas - UEA/CESP, Centro de Estudos Superiores de Parintins. Estrada Odovaldo Novo, km 1. 69152-470 Parintins, Amazonas, Brazil. FGT E-mail: fgtaddei@hotmail.com

2 Laboratório de Biologia de Camarões Marinhos e Dulcícolas (LABCAM), Departamento de Ciências Biológicas, Faculdade de Ciências, Universidade Estadual Paulista (UNESP). Av. Engenheiro Luis Edmundo Corrijo Coube, 14-01. 17033-360 Bauru, São Paulo, Brazil.

DRH E-mail: daphine_herrera@hotmail.com

TMD E-mail: tdavanso@hotmail.com

RCC E-mail: rccosta@fc.unesp.br

3 Núcleo de Estudos em Biologia, Ecologia e Cultivo de Crustáceos (NEBECC), Departamento de Zoologia, Instituto de Biociências de Botucatu, Universidade Estadual Paulista (UNESP). 18618-000 Botucatu, São Paulo, Brazil.

TES E-mail: thiagoel_8@hotmail.com

AFE-mail: fransozo@ibb.unesp.br

CORRESPONDING AUTHOR Fabiano Gazzi Taddei fgtaddei@hotmail.com

SUBMITTED 16 August 2016 ACCEPTED14 April 2017

PUBLISHED 20 July 2017

Guest Editor

Célio Magalhães

DOI 10.1590/2358-2936e2017022
ZOOBANK http://zoobank.org/urn:lsid:zoobank.org:pub:CDD55E93-0E1E-4BDBAC2F-D5519A380AB5

\section{Abstract}

This study describes the weight $v s$. carapace length relationship and provides the total and monthly condition factor values for populations of Macrobrachium jelskii (Miers, 1977) and M. brasiliense (Heller, 1868) occurring in southeastern Brazil. The biological characteristics were compared 
and related to the climatic environmental factors between the two areas. Our investigation sampled M. jelskii from the Barra Mansa Dam, Mendonça, SP, a semilotic environment with greater resilience than the Talhadinho Stream, Talhado, SP, a lotic environment where specimens of $M$. brasiliense were captured. Individuals were classified according to sex and measured at the carapace length (CL) and weighed (WE). The relationship WE/ $\mathrm{CL}$ was analyzed by dispersion diagrams of the empirical points, which were set to the power function (WE = a.CL ${ }^{b}$ ). Values of the mean condition factor were compared monthly. In total, 1493 individuals of M. jelskii and 843 individuals of $M$. brasiliense were captured. Analyses of the constant allometry revealed that both sexes of $M$. jelskii, as well as females of $M$. brasiliense grow proportionately more in size than weight. The results concerning the morphometric aspects studied in both species suggest an association with the reproductive processes.

\section{KEY WORDS}

Caridea, ecology, growth, limnology, reproduction, São Paulo State.

\section{INTRODUCTION}

The genus Macrobrachium Spence Bate, 1868 are distributed worldwide in tropical and subtropical waters (De Grave and Fransen, 2011; Pileggi and Mantelatto, 2012). In Brazil, this genus includes 19 species (Mantelatto et al., 2016), besides some introduced species, such as Macrobrachium rosenbergii (de Man, 1979) (New and Valenti, 2000; Melo, 2003). Some of the main species are used in shrimp farming, such as M. rosenbergii and Macrobrachium amazonicum (Heller, 1862), which are extensively studied for cultivation projects (Freire et al., 2012; David et al., 2016). Due to phenotypic plasticity, species of this genus occur in different types of environments, from estuarine to lotic and semi-lotic freshwater ecosystems (Pantaleão et al., 2012; Nobrega et al., 2014).

Macrobrachium jelskii (Miers, 1877), known as "ghost" shrimp, is a species endemic to South America that despite having a wide distribution is considered exotic in the state of São Paulo (Magalhães et al., 2005). This species has been used as fishing baits and serves as a food source for the riverine population. Also, this prawns plays a significant role in the food chain in limnic environments (Cirilo et al., 2011). These prawns are trophic generalists concerning the environment in which they inhabit (Montoya, 2003). They can be found in aggregate distribution in semilotic environments with dark water and low riparian vegetation, and also in lower density in lotic environments with clear and faster-moving water (Melo, 2003). Macrobrachium brasiliense (Heller, 1862) is native to South America and has a wide geographic distribution. The species is typical in lotic environments with abundant riparian vegetation and muddy-bottom waters (García-Dávila et al., 2000; Vásquez et al., 2000), and it inhabits shallow streams up to one meter deep (Mantelatto and Barbosa, 2005; Pereira and Chacur, 2011).

Some biological features of these two species are distinct, possibly due to ecological differences in the habitats where they live. According to Barros-Alves et al. (2012), M. jelskii exhibits a continuous breeding process, with females reaching larger sizes than males. In the Southeast and Midwest of Brazil, the reproductive period of $M$. brasiliense is restricted to the spring, with females smaller than males (Mantelatto and Barbosa, 2005; Pereira and Chacur, 2011).

These differences are considerably more striking in the species morphology, especially in males. The size of the second pair of pereiopods is similar between sexes in M. jelskii, whereas in M. brasiliense the same structure is pronounced and considerably larger in males when compared to females (Melo, 2003).

In fish and crustaceans species, the adaptation to environments can be verified by the condition factor (Rocha et al., 2015). This value is obtained by the weight gain/length gain ratio, which indicates the general welfare of the animal (Rodrigues et al., 1988; Susanto and Irnawati, 2014). The condition factor is related to a complex interaction of endogenous factors (Gopal et al., 2010), such as physiological, metabolic, hormonal, and genetic load processes (Gautam et al., 2014). The mechanisms mentioned above are modulated by exogenous factors, such as temperature, photoperiod, rainfall, salinity, availability/quality of food and population density (Araújo and Lira, 2012; Gautam et al., 2014). Furthermore, such analysis may 
reveal some reproductive traits of the species, such as spawning periods and gonadal maturation (Pinheiro and Taddei, 2005).

The present work describes the weight/length relationship and presents the total and the monthly condition factor for the prawn species M. jelskii and M. brasiliense. Moreover, this study compares the biological characteristics between both species in two locations with different environments on the Planalto Ocidental (Western Plateau) of the São Paulo State.

\section{Material and Methods}

Sampling was performed in two different regions located in the Western Plateau of São Paulo, Brazil. According to the Köppen classification (Peel et al., 2007), this area presents the AW climate type, which is characterized by summer (January to March) presenting rainfall and high temperatures, and winter (July to September) presenting dry and warm temperatures.

Individuals of $M$. jelskii were sampled monthly from October 1999 to September 2000, in the Barra Mansa Dam, municipality of Mendonça, São Paulo State $\left(21^{\circ} 14^{\prime} 27^{\prime \prime} S 49^{\circ} 56^{\prime} 28^{\prime \prime} \mathrm{W}\right)$. The damming of Borá and Cubatão rivers, tributaries of the Tiete River, forms an artificial lake with a drainage area of 13,395 $\mathrm{km}^{2}$ and exhibits a semilotic environment (Esteves, 1988). The author describes artificial dams as artificial barriers that create environmental settings, whose characteristics are intermediate between typical lotic and lentic systems.

Individuals of $M$. brasiliense were collected monthly from October 2001 to September 2002, in the Talhadinho Stream, municipality of Talhado, São Paulo State (20'47'07”S 49²0’35”W) (Fig. 1). The Talhadinho Stream is an affluent of the Turvo River, which is approximately $17 \mathrm{~km}$ long and features a lotic environment. This stream is up to one meter deep and shows a muddy substrate across its course, with interspersed rocks and branches, and heavy silting.

Sampling effort lasted 3 hours at each locality, in each month, with the presence of 3 collectors, and individuals were captured using sieves $(2 \mathrm{~mm}$ mesh size). Specimens of $M$. jelskii were captured under the sub-aquatic vegetation, while individuals of $M$. brasiliense were captured from the marginal habitats provided by the overhanging marginal vegetation. All the collected material was placed in labeled plastic bags and then transported to the laboratory where it remained under refrigeration.
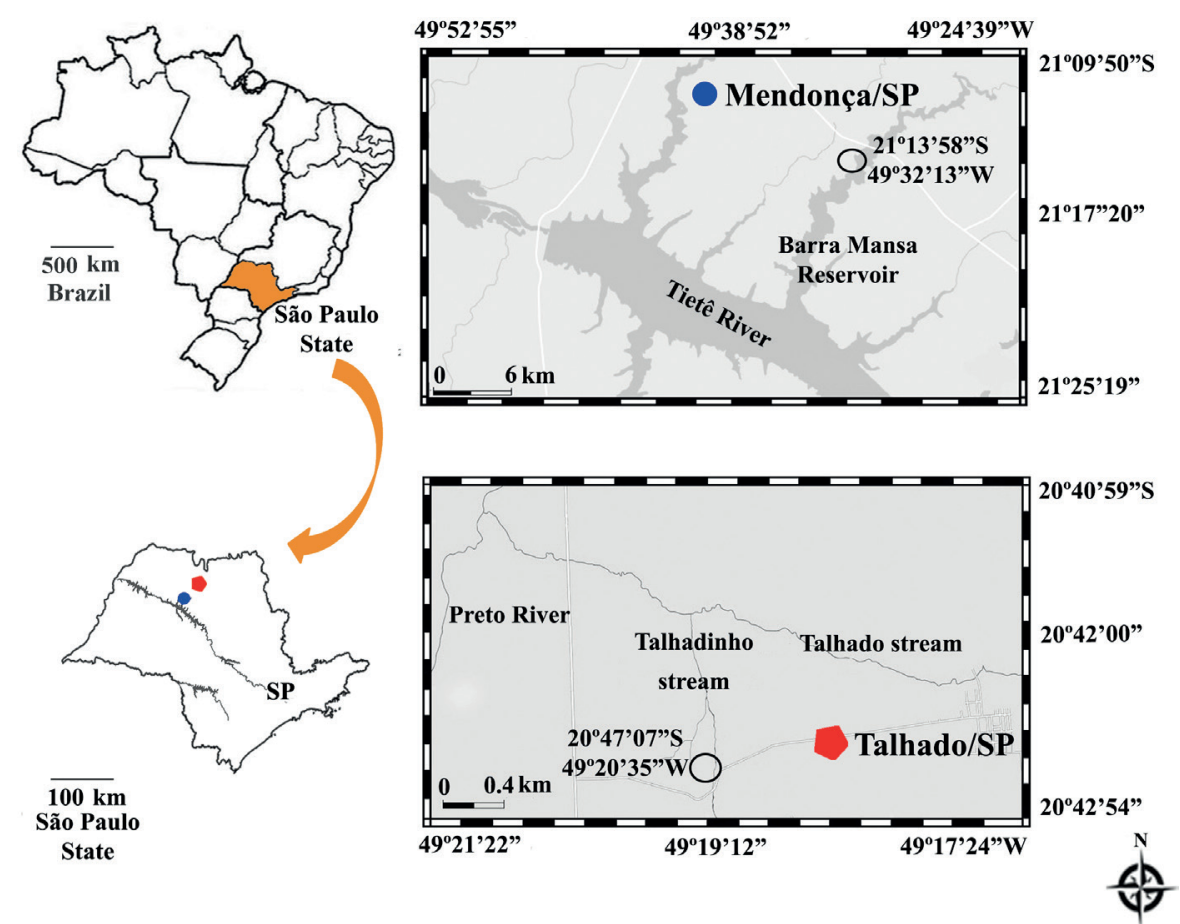

Figure 1. Sampling locations of specimens collected in São Paulo State, Brazil. A, Macrobrachium jelskii (Miers, 1877) collected in Mendonça; B, M. brasiliense (Heller, 1862) collected in Talhado. 
The specimens of $M$. jelskii were identified by the presence of an almost straight rostrum over the orbits, with the distal edge slightly curved upward, and particularly by the inner pair of telson spine overreaching the distal margin of telson (Magalhães et al., 2005). Macrobrachium brasiliense exhibits a straight rostrum reaching just beyond the eyestalk, with the first two teeth of the rostrum dorsal region located behind the eye socket (Melo, 2003).

Individuals were classified according to sex and identified by the presence (male) or absence (female) of the appendix masculina on the second pair of pleopods (Valenti, 1998). All specimens smaller than the smallest male (presence of an appendix masculina) were classified as undifferentiated juveniles (UJ), and they were not used in the analysis. Individuals with carapace length (CL) equal to or greater than that estimated for morphological sexual maturity were considered adults. In a study performed with the same populations of the present study (Taddei, 2006), the size for morphological sexual maturity of $M$. jelskii was established in $5.8 \mathrm{~mm}$ for males and $6.1 \mathrm{~mm}$ for females; for M. brasiliense, values were $10.9 \mathrm{~mm}$ and $16.6 \mathrm{~mm}$ for males and females, respectively.

Females whose abdomen presented eggs attached to the pleopods from the second abdominal somite were designated as ovigerous. The ratios of these ovigerous females were calculated according to the total number of females (ovigerous and non-ovigerous females) collected monthly.

Individuals were measured to the carapace length (CL), which corresponds to the distance from the posterior edge of orbit to the midpoint of the carapace posterior margin, using a digital caliper $(0.01 \mathrm{~mm})$. A precision scale $(0.01 \mathrm{~g})$ was used to obtain the wet weight (WE). Specimens with damaged carapace, missing or incomplete appendices, or in pre-molt stages or recently molted, were discarded from the analyses since these are factors that hamper the correct measurement.

The normality of the variables in each assay was verified using the Shapiro-Wilk test $(p=0.05)$. A regression analysis of males and non-ovigerous females was performed for the description of the weight (WE) vs. carapace length (CL). Then, data was set to the power function $\left(\mathrm{WE}=a \cdot \mathrm{CL}^{b}\right)$, where the weight $(\mathrm{WE})$ was considered as thought of as the dependent variable and the carapace length (CL) as the independent variable. After data linearization, the $b$ allometric constant value calculated for the biometric relationship of males and females was tested by formulating the null hypothesis $(\mathrm{H} 0: b=3)$ using the Student's $t$-test $(p=$ 0.05 ), corresponding to an isometry, if $b=3$; positive allometric, if $b>3$; and negative, if $b<3$.

The condition factor $a$ for every individual of each sex was estimated by the power function modified, i.e., $a=\mathrm{WE} / \mathrm{CL}^{b}$, where $b$ is the value obtained in the WE/CL relation of all individuals of the sex investigated (Okon and Sikoki, 2014). The monthly values were calculated for each sex separately and then compared using the analysis of variance (ANOVA) and the Tukey a posteriori comparison test (Zar, 2010). Such procedure verifies possible peak patterns and reductions in the condition factor in the species annual cycle.

Data on the abiotic factors, such as rainfall and temperature, was obtained at the Regional Agricultural Division (Divisão Regional Agrícola - DIRA) of each region. The relationship between these factors and the monthly values of the male and female condition factor were evaluated separately by Pearson's correlation coefficient. This test was also employed to investigate the association of the female condition factors of each species, with the monthly ratio of ovigerous females.

\section{ResULTS}

In total, 1,496 individuals of $M$. jelskii (3 undifferentiated juveniles, 513 males, 902 nonovigeorus females, and 78 ovigerous females Tab. 1) and 885 individuals of $M$. brasiliense ( 42 undifferentiated juveniles, 342 males, 495 females and 6 ovigerous females - Tab. 2) were captured. Monthly ratios of the collected females of both species are shown in Fig. 2.

The allometric coefficient values of $(b)$ showed different sexual patterns for each species. The females of $M$. jelskii presented greater allometric coefficient value when compared to males. The males of $M$. brasiliense exhibited higher values when compared to females $(t$-test, $p<0.05)$. The isometric/allometric conditions for each sex of each species are shown in Tab. 3. Regarding the condition factor $(a)$, there were also differences between species. The variation among females of $M$. jelskii was higher when compared to males 
Table 1. Size-class distribution of demographic groups of Macrobrachium jelskii (Miers, 1877) sampled in the Barra Mansa Dam, Mendonça, São Paulo State, Brazil (October 1999 to September 2000).

\begin{tabular}{|c|c|c|c|c|c|}
\hline \multirow{2}{*}{$\begin{array}{l}\text { Size-class } \\
\text { (CL mm) }\end{array}$} & \multirow{2}{*}{ UJ } & \multirow{2}{*}{ Males } & \multicolumn{2}{|c|}{ Females } & \multirow{2}{*}{ Total } \\
\hline & & & No & OF & \\
\hline $3-\mid 4$ & 3 & & & & 3 \\
\hline $4-15$ & & 33 & 51 & & 84 \\
\hline $5-16$ & & 187 & 155 & & 342 \\
\hline $6-17$ & & 114 & 294 & & 408 \\
\hline $7-8$ & & 81 & 177 & 12 & 270 \\
\hline $8-19$ & & 49 & 112 & 17 & 178 \\
\hline $9-10$ & & 28 & 74 & 28 & 130 \\
\hline $10-11$ & & 9 & 27 & 15 & 51 \\
\hline 12 & & 7 & 8 & 4 & 19 \\
\hline 13 & & 5 & 4 & 2 & 11 \\
\hline Total & 3 & 513 & 902 & 78 & 1496 \\
\hline
\end{tabular}

Note: $\mathrm{UJ}=$ undifferentiated juveniles; $\mathrm{NO}=$ non-ovigerous females; $\mathrm{OF}=$ ovigerous females; $\mathrm{CL}=$ carapace length.

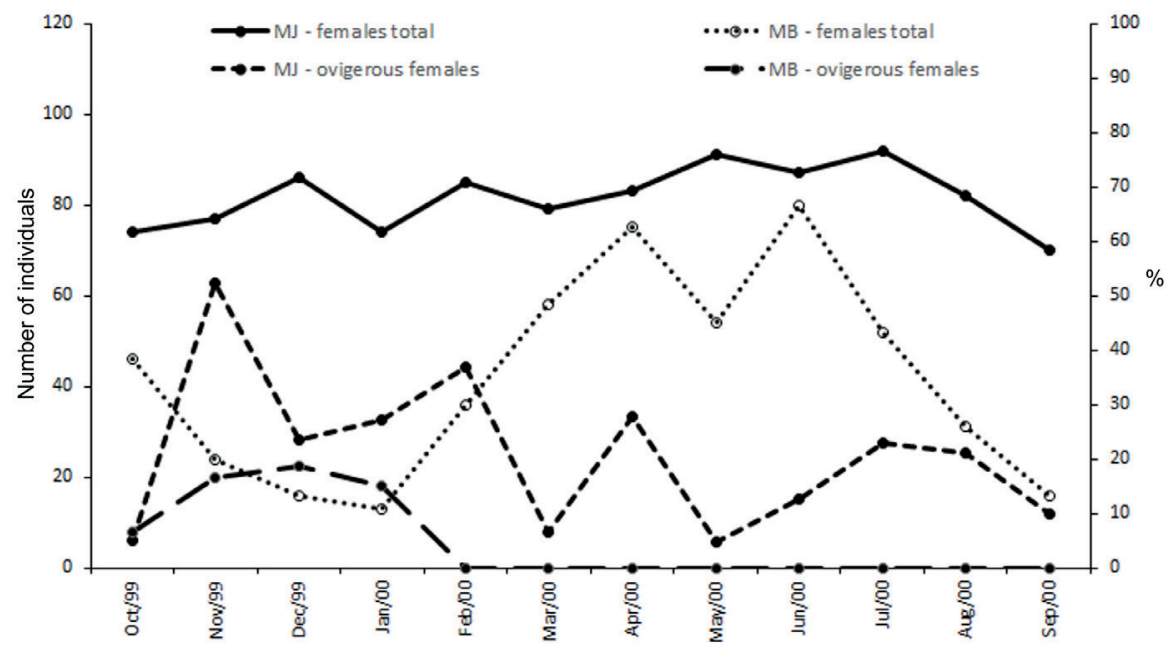

Figure 2. Monthly percentage of ovigerous and total females (ovigerous + non-ovigeorus) for the species. MJ = Macrobrachium jelskii (Miers, 1877) and MB = M. brasiliense (Heller, 1868) collected in the Barra Mansa Dam, Mendonça, São Paulo (October/1999 to September/2000) and Talhadinho Stream, Talhado, São Paulo (October/2001 to September/2002), respectively.

Table 2. Size-class distribution of demographic groups of Macrobrachium brasiliense (Heller, 1862) sampled in the Talhadinho Stream, Talhado, São Paulo State, Brazil (October 2001 to September 2002).

\begin{tabular}{|c|c|c|c|c|c|}
\hline \multirow{2}{*}{$\begin{array}{l}\text { Size-class } \\
(\mathrm{CL} \mathbf{~ m m})\end{array}$} & \multirow{2}{*}{ UJ } & \multirow{2}{*}{ Males } & \multicolumn{2}{|c|}{ Females } & \multirow{2}{*}{ Total } \\
\hline & & & No & OF & \\
\hline $0-2$ & 3 & & & & 3 \\
\hline $2-14$ & 39 & & & & 39 \\
\hline $4-6$ & & 69 & 151 & & 220 \\
\hline $6-18$ & & 85 & 163 & & 248 \\
\hline $8-10$ & & 69 & 106 & & 175 \\
\hline 12 | 12 & & 58 & 49 & & 107 \\
\hline 14 & & 33 & 6 & & 39 \\
\hline 16 | 14 & & 10 & 12 & 3 & 25 \\
\hline 18 & & 12 & 8 & 3 & 23 \\
\hline 20 & & 3 & & & 3 \\
\hline $20-22$ & & 1 & & & 1 \\
\hline $22-24$ & & 2 & & & 2 \\
\hline Total & 42 & 342 & 495 & 6 & 885 \\
\hline
\end{tabular}

Note: $\mathrm{UJ}=$ undifferentiated juveniles; $\mathrm{NO}=$ non-ovigerous females; $\mathrm{OF}=$ ovigerous females; $\mathrm{CL}=$ carapace length. 
( $t$-test, $p<0.05)$, despite of the condition factor did not differ significantly between sexes in $M$. brasiliense ( $t$-test, $p>0.05)$. The linearized equations for both sexes of each species and the respective analyses of the constants are shown in Tab. 4.

\section{Macrobrachium jelskii}

The mean size obtained for males was $6.76 \pm 2.05$ $\mathrm{mm}(\mathrm{CL})$, and did not differ significantly from females, whose values were $6.89 \pm 1.62 \mathrm{~mm}(\mathrm{CL})(t$-test, $p>$ $0.05)$. The mean weight (WE) of males was $0.31 \pm 0.13$ $\mathrm{g}$ and was statistically different from the data obtained for the females: $0.37 \pm 0.19 \mathrm{~g}(t$-test, $p<0.05)$.

The WE and CL variables were positively correlated. The model proposed for adjusting the ratio for both sexes showed the determination coefficient with considerable values $\left(\mathrm{R}^{2}=0.89\right.$ and 0.88 for males and females, respectively). The equations for each sex are shown separately in Figs. 3 and 4, and both exhibited negative allometric values, 1.61 and 2.16 , respectively (Tab. 3).

The mean condition factor obtained for males (0.0133) was significantly lower than that for females $(0.0543)(t$-test, $p<0.05)$. The analyses of monthly variances of the condition factor in males did not show statistically significant differences $(p>0.05, \mathrm{r}=0.338)$. Females presented the highest values in June/2000 (0.7862) and the lowest (0.2667) in November / 1999 (Fig. 5).

The condition factor values of males did not show any correlation with temperature and rainfall. Also, the condition factor values of females did not correlated with temperature $(p>0.05)$ (Fig. 6) and were not associated with ovigerous female ratio $(p>0.05)$.

Table 3. Results of the allometric analysis of the weight (WE) vs. carapace length (CL) relationship for Macrobrachium jelskii (Miers, 1877) sampled in the Barra Mansa Dam, Mendonça (October 1999 to September 2000) and Macrobrachium brasiliense (Heller, 1868) sampled in the Talhadinho Stream, Talhado (October 2001 to September 2002), both localities in the São Paulo State, Brazil.

\begin{tabular}{|c|c|c|c|c|c|c|c|c|c|c|}
\hline \multirow[b]{2}{*}{$\begin{array}{l}\text { Factor } \\
\text { (Group) }\end{array}$} & \multicolumn{5}{|c|}{ Macrobrachium jelskii } & \multicolumn{5}{|c|}{ Macrobrachium brasiliense } \\
\hline & $\mathbf{N}$ & $b$ & $\mathbf{r}^{2}$ & $\begin{array}{c}T \\
(b=3)\end{array}$ & allometry & $\mathbf{N}$ & $b$ & $\mathbf{r}^{2}$ & $\begin{array}{c}\mathbf{T} \\
(\mathbf{b}=3)\end{array}$ & allometry \\
\hline Males & 513 & 1.61 & 0.89 & 98.4 & - & 342 & 3.08 & 0.89 & 98.4 & $\varnothing$ \\
\hline Females & 902 & 2.16 & 0.84 & 48.41 & - & 495 & 2.64 & 0.84 & 48.41 & - \\
\hline
\end{tabular}

Note: $\mathrm{N}=$ number of specimens; $b=$ slope; $\mathrm{r}^{2}=$ determination coefficient; $\mathrm{T}=$ statistical values $(\mathrm{p}<0.001)$; allometry $=$ - negative, $\emptyset$ isometry.

Table 4. Linearized equations for the relationship of weight (WE) vs. carapace length (CL) for all individuals of the species Macrobrachium jelskii (Miers, 1877) sampled in the Barra Mansa Dam, Mendonça, São Paulo (October/1999 to September/2000) and Macrobrachium brasiliense (Heller, 1868) sampled in the Talhadinho Stream, Talhado (October 2001 to September 2002), both localities in the São Paulo State, Brazil.

\begin{tabular}{|c|c|c|c|c|}
\hline Species & Sex & Equation & $\mathbf{N}$ & $\mathbf{r}^{2}$ \\
\hline \multirow{2}{*}{ M. jelskii } & $\mathrm{M}$ & $\operatorname{lnWE}=-4.31^{*}+1.61^{*} \ln C L$ & 513 & 0.89 \\
\hline & $\mathrm{F}$ & $\operatorname{lnWE}=-5.3+2.16 \operatorname{lnCL}$ & 902 & 0.84 \\
\hline \multirow{2}{*}{ M. brasiliense } & M & $\operatorname{lnWE}=-7.41+3.08^{*} \ln C L$ & 342 & 0.93 \\
\hline & $\mathrm{F}$ & $\ln W E=-6.31+2.64 \ln C L$ & 495 & 0.97 \\
\hline
\end{tabular}

Note: $\mathrm{N}$ = number of specimens; $\mathrm{r} 2$ = determination coefficient; ${ }^{*}$ Value statistically divergent from that obtained for females $(\mathrm{t}$-test, $\mathrm{p}<0.05) ; \mathrm{M}=$ male; $\mathrm{F}=$ female.

\section{Macrobrachium brasiliense}

The mean size obtained for males of this species was $10.71 \pm 4.12 \mathrm{~mm}(\mathrm{CL})$, significantly higher than those found for females, i.e., $8.76 \pm 3.83 \mathrm{~mm}(\mathrm{CL})(t$-test, $p$ $<0.05$ ). The mean weight (WE) of males was $1.23 \pm$ $0.92 \mathrm{~g}$ and diverged from the females, which presented $0.65 \pm 0.56 \mathrm{~g}(t$-test, $p<0.05)$.
The WE and CL variables also showed a positive correlation with significant determination coefficients $\left(\mathrm{R}^{2}\right)$ in males and females (0.93 and 0.97, respectively). Figs. 7 and 8 show equations for males and females, respectively. Males presented isometry in the relationship $(b=3.08)$, while females exhibited negative allometry $(b=2.64)$ (Tab. 3$)$. 


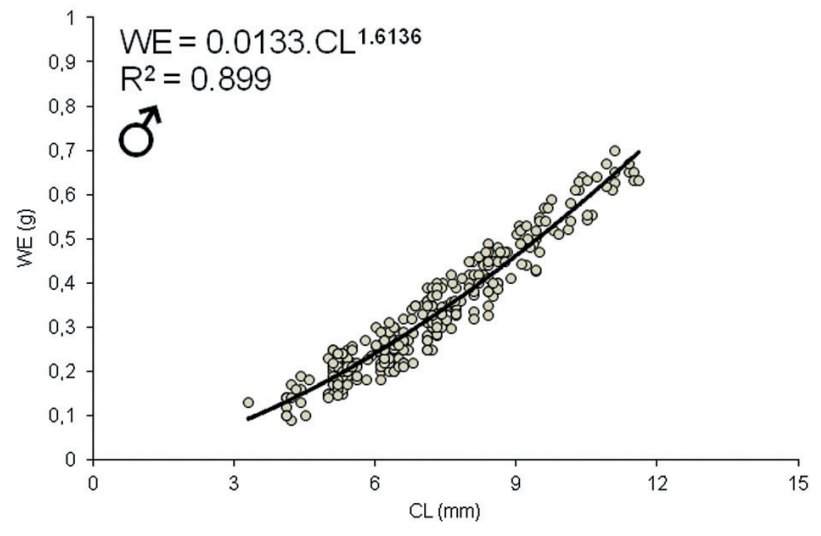

Figure 3. Macrobrachium jelskii (Miers, 1877). Dispersion of empirical points of the WE vs. CL relationship for males and adjustment to the power function. Specimens were collected in the Barra Mansa Dam, Mendonça, São Paulo (October/1999 to September/2000).

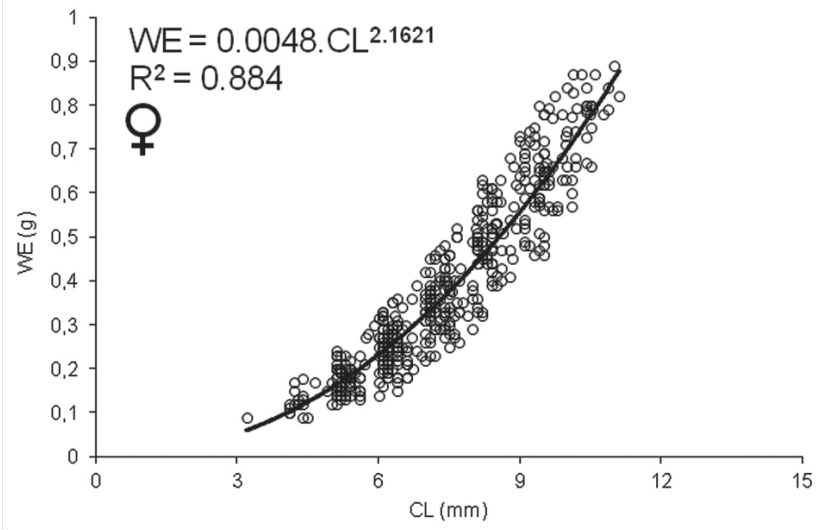

Figure 4. Macrobrachium jelskii (Miers, 1877). Dispersion of empirical points of the WE vs. CL relationship for females and adjustment to the power function. Specimens were collected in the Barra Mansa Dam, Mendonça, São Paulo (October/1999 to September/2000).

The mean condition factor obtained for males was $0.038837 \pm 0.0094$, which was significantly different when compared to the females, which presented $0.02787 \pm 0.004623$ ( $t$-test, $p<0.05)$. The analysis of monthly variations of the condition factor in males showed no statistically significant differences ( $t$-test, $p>0.05)$. For females, the highest monthly condition factor (0.054033) was obtained in December (2001) and the lowest (0.013493) in March (2002) (Fig. 9). The monthly condition factor values of males and females exhibited no relationship, either with the investigated abiotic factors $(p>0.05)$ or the ovigerous female ratio $(p>0.05)$.

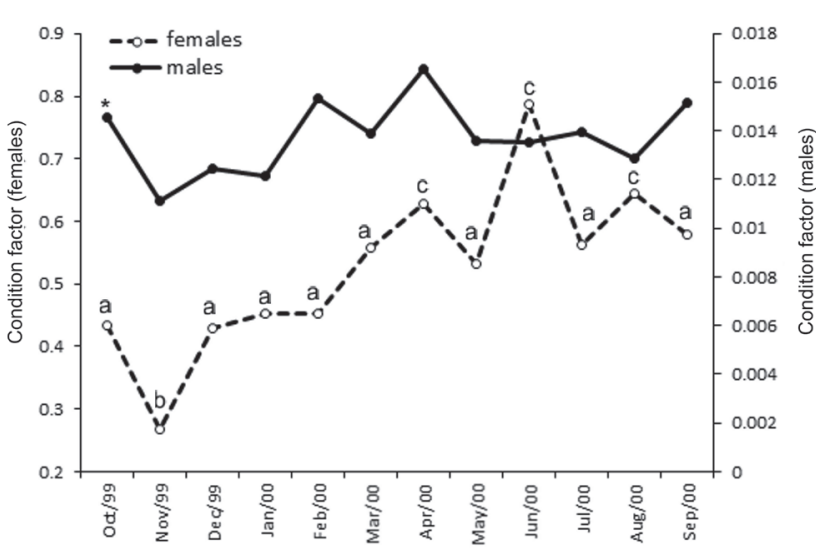

Figure 5. Macrobrachium jelskii (Miers, 1877). Average of the monthly condition factor of males and females collected in the Barra Mansa Dam, Mendonça, São Paulo (October/1999 to September 2000$)$. Same letter in common indicates no significant difference in post-hoc Tukey test $(p>0.05) .{ }^{*}$ No significant differences were observed in the monthly averages of males (ANOVA, $\mathrm{p}>0.05$ ).

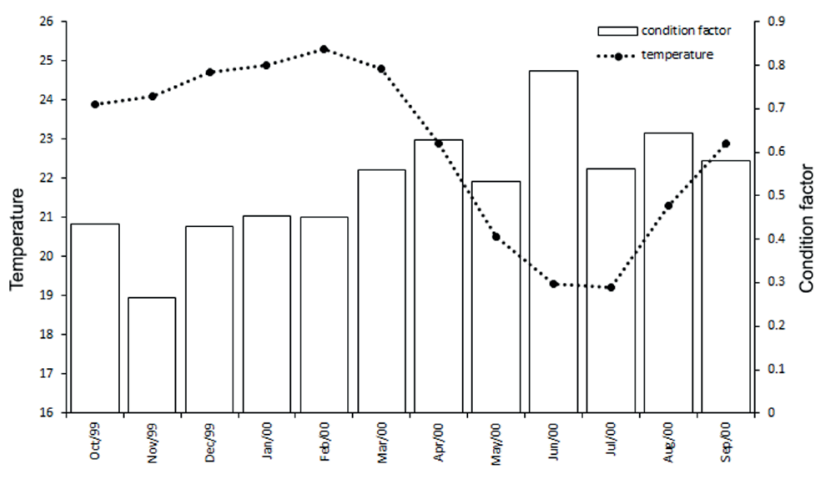

Figure 6. Macrobrachium jelskii (Miers, 1877). Relationship between monthly condition factor average of females of the species and monthly average temperature of the Barra Mansa Dam, Mendonça, São Paulo (October/1999 to September/2000).

\section{Discussion}

The increase in weight observed in the present study for M. jelskii and M. brasiliense is similar to the pattern previously observed in other decapod crustaceans, which varies from 2 to 4 (Hartnoll, 1982). The adjustment of the empirical points to the power function showed statistically significant results $\left(R^{2}\right)$. The analysis of the allometric constant of this equation revealed that both sexes in $M$. jelskii and females of $M$. brasiliense exhibit the constant value $b$ smaller than 3. This characteristic is common in species of this genus, such as Macrobrachium acanthurus (Wiegmann, 1836), Macrobrachium potiuna (Müller, 1880), and M. 


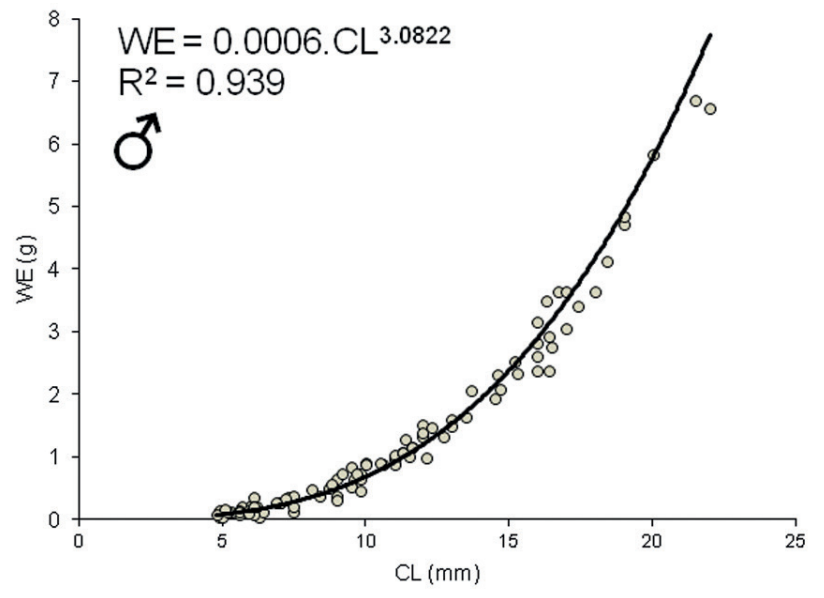

Figure 7. Macrobrachium brasiliense (Heller, 1877). Dispersion of empirical points of the WE $v s$. CL relationship for males and adjustment to the power function. Specimens were collected in the Talhadinho Stream, Talhado, São Paulo (October/2001 to September/2002).

amazonicum (Valenti et al., 1989; Souza and Fontoura, 1995; Silva et al., 2007; Nobrega et al., 2014). The males of $M$. brasiliense showed isometric growth for the variables analyzed, indicating the proportional increase between size and weight.

Variations in allometry of decapod crustaceans can result from differentiated diet, increased feed conversion ratio, or increase in the weight of males after maturity (Bliss, 1983; Sagi and Khalaila, 2001). The androgenic gland, functional in adult males, promotes the gonadal development even if individuals are not in the reproductive period, thus increasing the weight and, consequently, the condition factor. In crustaceans, the body growth occurs by successive molts dependent upon physiological aspects regulated by abiotic factors, such as photoperiod, temperature, and rainfall (Hartnoll, 1982).

Compared to lotic environments, dammed areas exhibit higher resilience (Robertson, 2000), which allows $M$. jelskii to present continuous reproductive periods. The greatest changes in the stream environmental conditions, in which $M$. brasiliense inhabits, favor reproduction only in the period of greatest rainfall. Probably, at this time, the allochthonous detritus provides food to the larvae (Bentes et al., 2011).

In general, gonadal development is the most significant biological characteristic of the weight in decapod crustaceans, as highlighted by Susanto and Irnawati (2014) for Thalamita crenata (Latreille,

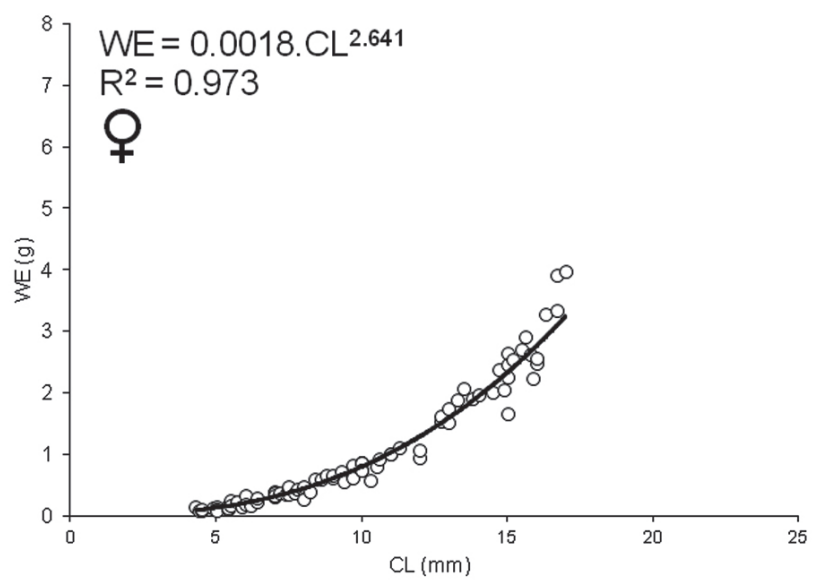

Figure 8. Macrobrachium brasiliense (Heller, 1877). Dispersion of empirical points of the WE $v$ s. CL relationship for females and adjustment to the power function. Specimens were collected in the Talhadinho Stream, Talhado, São Paulo (October/2001 to September/2002).

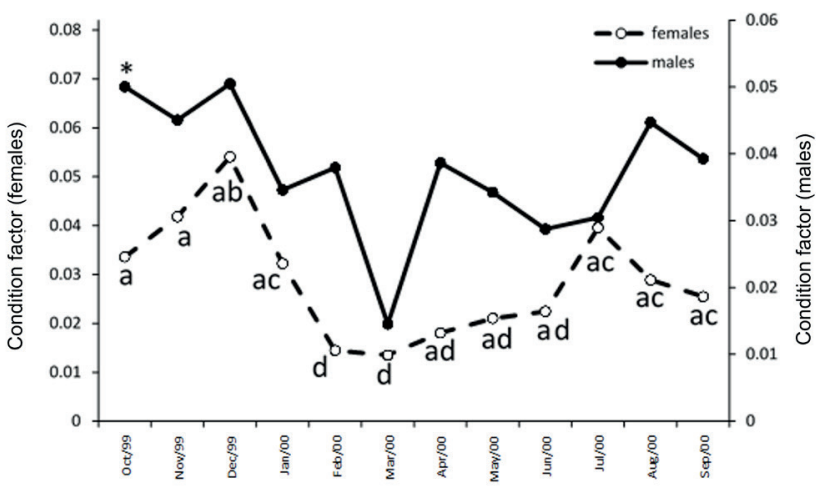

Figure 9. Macrobrachium brasiliense (Heller, 1868). Average of the monthly condition factor for males and females collected in the Talhadinho Stream, Talhado, São Paulo (October/2001 to September/2002). Same letter in common indicates no significant difference in post-hoc Tukey test $(p>0.05) .{ }^{*}$ No significant differences were observed in the monthly averages for the males (ANOVA, $p>0.05$ ).

1829) of the Portunidae family. This development occurs markedly in adult females, whose ovaries can exceed almost three times the weight of male testes of Dilocarcinus pagei Stimpson, 1861, a freshwater Brachyura (Pinheiro and Taddei, 2005). Differences are even greater in freshwater prawns of family Palaemonidae, due to the production of large amounts of vitellus (Parker, 1992), a feed source crucial to the survival of larvae in the early stages (Meireles et al., 2013).

Females of M. jelskii exhibited higher values of the allometric constant when compared to males, which is probably related to the presence of developed gonads 
during most part of the year. Such data are in agreement with the highest values of the condition factor, which were recorded during the months when the numbers of adult females with mature gonads were significantly greater than the number of males.

Continuous reproduction is typical of $M$. jelskii (see Barros-Alves et al., 2012). This species exhibits lower average body size than $M$. brasiliense, so the difference in the condition factor of individuals with developed gonads is more representative, as evidenced by the significant variations in the monthly values throughout the year.

Males of M. jelskii may be favored by the greater body growth over weight increase. The higher number of males able for reproduction in a shorter time period allows a greater transfer of gametes and so be more advantageous for the species. According to Bauer (2004), shrimp species distributed in clusters present a "pure search" mating behavior, in which there are neither agonistic interactions between males nor courting of females. In this type of behavior, the gametes are transferred to several females, which can explain the sex ratio skewed toward females in the population of this species, observed in this study and substantiated by Barros-Alves et al. (2012). Another hypothesis for the sex ratio found for M. jelskii is possibly the different spatial distribution between sexes in large dammed water bodies.

The highest growth rate found for males of M. jelksii corroborated with the smaller size found for this sex. Analyses of crustacean growth (Davanso et al., 2013; Taddei et al., 2015) showed that individuals with the highest growth rate reach the smaller maximum size, as evidenced by the equation that estimates these variables (see Bertalanffy, 1938).

The monthly analysis of the condition factor of males indicated a lower value in November/1999, when the highest ratio of ovigerous females occurred. The presence of a greater number of females at that time can explain this result and may be also related with the highest values of the male condition factor. These values resulted from the influence of the weight of the gonads developed in the reproduction period.

Males of $M$. brasiliense increase in weight proportionately greater than females. The different increase in weight between sexes is related to the larger body size and larger chelipeds in males (Boschi,
1974; Pantaleão et al., 2014), as well as the gonadal development in adults over an extended period, and the slower growth rate when compared to females, as explained for M. jelskii. Additionally, females of $M$. brasiliense develop gonads only one period of the year, which reduces their weight and results in a negative allometric growth (Taddei, 2006).

Analyses of the monthly condition factor in $M$. brasiliense showed a similar pattern for both sexes. The reproductive period (October to January) probably influenced the higher values of the condition factor because of the increased gonad development occurred in this time. The lowest condition factor value (March) occurred exactly in the month following the end of the reproduction season. The subsequent months are marked by the reorganization of the gonads (Barbieri and Verani, 1987). The reorganization of the gonadal cycles is slow, probably due to the need for large amounts of necessary nutrients throughout the process.

The results found in the present study suggest that the weight and, consequently, its relationship with the size and condition of both species are related to reproduction. The key factor investigated is endogenous, i.e., the reproductive organs, particularly the female gonads, constitute one of the most critical components that influence shrimp total weight.

The results obtained for the morphometric aspects investigated in both species also suggest an association with the reproductive processes. Gonadal development, especially vitellogenesis, increases the shrimp weight (in females), so the reproductive period may be a response to the endogenous factors that trigger the weight gain in the individual. Moreover, the molting process must also be considered in the weight gain, given that depending on the molting stage, individuals may lose or gain water and thus influence the weight. In this sense, more detailed studies should be conducted to evaluate which are the factors modulating this process of weight growth in caridean freshwater shrimps.

\section{ACKNOWLEDGEMENTS}

The authors would like to thank the Prof. Dr. Maria Lúcia Negreiros Fransozo for the review and valuable suggestions to the present manuscript, to Dr. Célio Magalhães for the identification of species. We are also grateful to Rio Preto University Center (Centro Universitário de Rio Preto - UNIRP) for providing 
the laboratory for the accomplishment of the analysis of the biological material. RCC thanks Conselho Nacional de Desenvolvimento Científico e Tecnólogico (CNPq) for the Research Scholarships support (PQ\# 305919/2014-8). All experiments conducted in this study complied with current applicable state and federal laws in Brazil (Sistema de Autorização e Informação em Biodiversidade - SISBIO No. 25056-1).

\section{RefERENCES}

Araújo, M.S.L.C. and Lira, J.J.P.R. 2012. Condition factor and carapace width versus wet weight relationship in the swimming crab Callinectes danae Smith 1869 (Decapoda, Portunidae) at the Santa Cruz Channel, Pernambuco State, Brazil. Nauplius, 20: 41-50.

Barbieri, G. and Verani, J.R. 1987. O fator de condição como indicador do período de desova em Hypostomus aff. plecostomus (Linnaeus, 1758) (Osteichthyes, Loricariidae), na Represa do Monjolinho (São Carlos, SP). Ciência e Cultura, 39: 655-658.

Barros-Alves, S.D.P.; Almeida, A.C.; Fransozo, V.; Alves, D.F.R.; Silva, J.C.D. and Cobo, V.J. 2012. Population biology of shrimp Macrobrachium jelskii (Miers, 1778) (Decapoda, Palaemonoidea) at the Grande River at northwest of the state of Minas Gerais, Brazil. Acta Limnologica Brasiliensia, 24: $266-275$.

Bauer, R.T. 2004. Remarkable shrimps: adaptations and natural history of the Carideans. Norman, University of Oklahoma Press, 279p.

Bentes, B.S.; Martinelli, J.M.; Souza, L.S.; Cavalcante, D.V.; Almeida, M.C. and Isaac, V.J. 2011. Spatial distribution of the Amazon River prawn Macrobrachium amazonicum (Heller, 1862) (Decapoda, Caridea, Palaemonidae) in two perennial creeks of an estuary on the northern coast of Brazil (Guajará Bay, Belém, Pará). Brazilian Journal of Biology, 71: 925-935.

Bertalanffy, L. von. 1938. A quantitative theory of organic growth. Human Biology, 10: 181-213.

Boschi, E.E. 1974. Biología de los crustáceos cultivables en América Latina. p. 1-24. In: FAO, Actas del Simposio sobre Acuicultura en América Latina. Informe de Pesca 159, vol. 2. Montevideo, Uruguay.

Cirilo, A.T.O.; Santos, M.C. and Nunes, M.L. 2011. Caracterização física e nutricional do camarão "saburica" (Macrobrachium jelskii, Miers, 1877) e de produtos derivados. Scientia Plena, 7: $1-6$.

Davanso, T.M.; Taddei, F.G.; Simões, S.M.; Fransozo, A. and Costa, R.C. 2013. Population dynamics of the freshwater crab Dilocarcinus pagei in tropical waters in southeastern Brazil. Journal of Crustacean Biology, 33: 235-243.

David, F.S.; Cohen, F. and Valenti, W.C. 2016. Intensification of the giant river prawn Macrobrachium rosenbergii hatchery production. Aquaculture Research, 47: 3747-3752.

De Grave, S. and Fransen, C.H.J.M. 2011. Carideorum catalogus: the recent species of the dendrobranchiate, stenopodidean, procarididean and caridean shrimps (Crustacea: Decapoda). Zoologische Mededelingen, 89: 195-589.

Esteves, F.A. 1988. Fundamentos de Limnologia. São Paulo, Editora Interciência/FINEP, 288p.

Freire, J.L.; Marques, C.B. and Silva, B.B. 2012. Estrutura populacional e biologia reprodutiva do camarão-da-amazônia Macrobrachium amazonicum (Heller,1862) (Decapoda: Palaemonidae) em um estuário da região nordeste do Pará, Brasil. Brazilian Journal of Aquatic Science and Technology, 16: 65-76.

Garcia-Dávila, G.; Alcântara, C.R.; Vasquez, F.B. and Chujandamas, E.R. 2000. Biologia reprodutiva do camarão Macrobrachium brasiliense (Heller, 1862) (Crustacea: Decapoda: Palaemonidae) em igarapés de terra firme da Amazônia Peruana. Acta Amazonica, 30: 653-664.

Gautam, K.; Nazar, A.R.; Ganesh, E.A.; Mahendran, S. and Mahadevan, G. 2014. Study of lenght and weight relationship of Litopenaeus vannamei (Boone, 1931) from east coast of India. International Journal of Science Inventions Today, 3: 365-376.

Gopal, C.; Gopikrishna, G. and Krishna G. 2010. Weight and time of onset of female-superior sexual dimorphism in pond reared Penaeus monodon. Aquaculture, 300: 237-239.

Hartnoll, R.G. 1982. Growth. p. 111-196. In: L.G. Abele and D.E. Bliss (eds), The Biology of Crustacea: Embriology, morphology and genetics. New York, Academic Press.

Magalhães, C.; Bueno, S.L.; Bond-Buckup, G.; Valenti, W.C.; Silva, H.M.; Kiyohara, F.; Mossolin, E.C. and Rocha, S. 2005. Exotic species of freshwater decapod crustaceans in the state of São Paulo, Brazil: records and possible causes of their introduction. Biodiversity and Conservation, 14: 1929-1945.

Mantelatto, F.L.M. and Barbosa, L.R. 2005. Population structure and relative growth of freshwater prawn Macrobrachium brasiliense (Decapoda, Palaemonidae) from São Paulo State, Brazil. Acta Limnologica Brasiliensia, 17: 245-255.

Mantelatto, F.L.; Pileggi, L.G.; Magalhães, C.; Carvalho, F.L.; Rocha, S.S.; Mossolin, E.C.; Rossi, N. and Bueno, S.L.S. 2016. Avaliação dos Camarões Palemonídeos (Decapoda: Palaemonidae), p. 252-267. In: M.A.A. Pinheiro and H. Boos, (Org.). Livro Vermelho dos Crustáceos do Brasil: Avaliação 2010-2014. Porto Alegre, Sociedade Brasileira de Carcinologia - SBC, 466p.

Meireles, A.L.; Valenti, W.C. and Mantelatto, F.L.M. 2013. Reproductive variability of the Amazon River prawn, Macrobrachium amazonicum (Caridea, Palaemonidae): influence of life cycle on egg production/Variabilidad reproductiva del camarón del río Amazonas, Macrobrachium amazonicum (Caridea, Palaemonidae): influencia del ciclo de vida en la fecundidad. Latin American Journal of Aquatic Research, 41: 718-731.

Melo, G.A.S. 2003. Famílias Atyidae, Palaemonidae e Sergestidae. p. 289-409. In: G.A.S. Melo (ed.), Manual de identificação dos Crustacea Decapoda de água doce do Brasil. São Paulo: Edições Loyola 
Montoya,J.V.2003. Freshwater shrimps of the genus Macrobrachium associated with roots of Eich hornia crassipes (Water Hyacinth) in the Orinoco Delta (Venezuela). Caribbean Journal of Science, 39: $155-159$.

New, M.B. and Valenti, W.C. Freshwater. 2000. Prawn Culture: the Farming of Macrobrachium rosenbergii. Oxford, Blackwell, $435 \mathrm{p}$.

Nóbrega, P.S.V.D.; Bentes, B. and Martinelli-Lemos, J.M. 2014. Population structure and relative growth of the Amazon shrimp Macrobrachium amazonicum (Heller, 1862) (Decapoda: Palaemonidae) on two islands in the fluvial-estuarine plain of the Brazilian Amazon. Nauplius, 22: 13-20.

Okon, E.A. and Sikoki, F.D. 2014. Length-weight relationship and condition factor of the West African fiddler crab (Uca tangeri) in Mbo River, AkwaIbom state, Nigeria. Journal of Natural Sciences Research, 4: 33-41.

Pantaleão, J.A.F.; Hirose, G.L. and Costa, R.C. 2012. Relative growth, morphological sexual maturity, and size of Macrobrachium amazonicum (Heller 1862) (Crustacea, Decapoda, Palaemonidae) in a population with an entirely freshwater life cycle. Invertebrate Reproduction \& Development, 56: $180-190$.

Pantaleão, J.A.F., Hirose, G.L. and Costa, R.C. 2014. Ocurrence of male morphotypes of Macrobrachium amazonicum (Caridea, Palaemonidae) in a population with an entirely freshwater life cycle. Brazilian Journal of Biology, 74: 223-232.

Parker, G.A. 1992. The evolution of sexual dimorphism. Journal of Fish Biology, 41: 1-20.

Peel, M.C.; Finlayson, B. L. and McMahon, T.A. 2007. Updated world map of the Köppen-Geiger climate classification. Hydrology and Earth System Science, 11: 1633-1644.

Pereira, M.D.G.C. and Chacur, M.M. 2011. Estrutura populacional de Macrobrachium brasiliense (Crustacea, Palaemonidae) do Córrego Escondido, Batayporã, Mato Grosso do Sul, Brasil. Revista de Biologia Neotropical, 6: 75-82.

Pileggi, L.G. and Mantelatto, F.L.M. 2012. Taxonomic revision of doubtful Brazilian freshwater shrimp species of genus Macrobrachium (Decapoda, Palaemonidae). Iheringia, 102: 426-437.

Pinheiro, M.A.A. and Taddei, F.G. 2005. Relação peso/largura da carapaça e fator de condição em Dilocarcinus pagei Stimpson (Crustacea, Trichodactylidae), em São José do Rio Preto, São Paulo, Brasil. Revista brasileira de Zoologia, 22: 825-829.

Powers, L.W. and Bliss, D.E. 1983. Terrestrial adaptations. p. 271333. In: M.D. Vernberg and W. Vernberg (eds), The biology of Crustacea. Environmental adaptations, Vol. 8. New York, Academic Press.

Robertson, A.L. 2000. Lotic meiofaunal community dynamics: colonisation, resilience and persistence in a spatially and temporally heterogeneous environment. Freshwater Biology, 44: 135-147.
Rocha, S.S.D.; Silva, R.L.S.D.; Santos, J.D.L. and Oliveira, G.D. 2015. Length-weight relationship and condition factor of Macrobrachium amazonicum (Heller, 1862) (Decapoda, Palaemonidae) from a reservoir in Bahia, Brazil. Nauplius, 23: $146-158$.

Rodrigues, A.M.; Rodrigues, J.D.; Moraes, M. N. and Ferreira, A.E. 1988. Aspectos da estrutura populacional da pescada do Piauí Plagioscion squamosissimus (Heckel, 1840) (Osteichthyes, Sciaenidae), na Represa de Bariri, Rio Tietê, Estado de São Paulo, Brasil. Boletim do Instituto de Pesca, 15: 155-157.

Sagi, A. and Khalaila, I. 2001. The crustacean androgen: A hormone in an isopod and androgenic activity in decapods. American Zoologist, 41: 477-484.

Silva, M.C.N.; Frédou, F.L. and Souto-Filho, J. 2007. Estudo do crescimento do camarão Macrobrachium amazonicum (Heller, 1862) da Ilha de Combú, Belém, Estado do Pará. Amazônia: Ciência e Desenvolvimento, 2: 85-104.

Souza, G.D. and Fontoura, N.F. 1995. Crescimento de Macrobrachium potiuna no Arroio Sapucaia, Município de Gravataí, Rio Grande do Sul (Crustacea, Decapoda, Palaemonidae). Revista Brasileira de Biologia, 55: 51-63.

Susanto, A. and Irnawati, R. 2014. Length-weight and widthweight relationship of spiny rock crab Thalamita crenata (Crustacea, Decapoda, Portunidae) in Panjang Island Banten Indonesia. Bioflux, 7: 148-152.

Taddei, F.G. 2006. Biologia populacional, reprodutiva e crescimento dos camarões de água doce Macrobrachium jelskii (Miers, 1877) e Macrobrachium brasiliense (Heller, 1862) na região noroeste do estado de São Paulo. Universidade Estadual Paulista - UNESP, Botucatu, Brazil, Ph.D. Thesis. 217p. [Unpublished].

Taddei, F.G; Davanso, T. M.; Castiglioni, L.; Herrera, D.R.; Fransozo, A. and Costa, R.C. 2015. Population structure, recruitment, and mortality of the freshwater crab Dilocarcinus pagei Stimpson, 1861 (Brachyura, Trichodactylidae) in Southeastern Brazil. Invertebrate Reproduction \& Development, 59: 189-199.

Valenti, W.C. 1998. Carcinicultura de água doce: Tecnologia para a produção de camarões. São Paulo, Fundação de Amparo à Pesquisa do Estado de São Paulo; Brasília, Instituto Brasileiro do Meio Ambiente e dos Recursos Naturais Renováveis (IBAMA), 383p.

Valenti, W.C.; Mello, J.D.T. and Lobão, V.L. 1989. Fecundidade em Macrobrachium acanthurus (Wiegmann, 1836) do Rio Ribeira de Iguape (Crustacea, Decapoda, Palaemonidae). Revista brasileira de Zoologia, 6: 9-15.

Vasquez, E.; Chujandama, M.; García, C. and Alcântara, F. 2000. Caracterización del hábitat del camarón Macrobrachium brasiliense en ambientes acuáticos de la carretera IquitosNauta. Folia Amazónica, 10: 57-63.

Zar, J.H. 2010. Biostatistical Analysis. New Jersey, Pearson Prentice-Hall, 944p. 